\section{Evaluation and Comparison of Postharvest Cooling Methods on the Microbial Quality and Storage of Florida Peaches}

\author{
Jaysankar De ${ }^{1}$, Bruna Bertoldi ${ }^{1}$, Mohammad Jubair ${ }^{1}$, \\ Alan Gutierrez ${ }^{1}$, Jeffery K. Brecht ${ }^{2}$, Steven A. Sargent ${ }^{2}$, \\ and Keith R. Schneider ${ }^{1}$
}

\begin{abstract}
ADDITIONAL INDEX WORDs. aerobic plate counts, forced-air cooling, hydrocooling, room-cooling, yeast and mold counts

Summary. Florida peaches (Prunus persica) typically are picked and placed in a cold room on the day of harvest, then packed and shipped the next day. This room cooling $(\mathrm{RC})$ is slow, requiring $\approx \mathbf{2 4}$ hours or more for the fruit to reach optimal temperature $\left(6\right.$ to $\left.7^{\circ} \mathrm{C}\right)$. There is currently limited research on the effect of cooling practices on microbial quality of peaches, yet this study is essential for decision making in areas such as upgrading packing house facilities and the implementation of improved handling procedures. This research compared the efficacies of postharvest cooling by RC, forced-air cooling (FAC), and hydrocooling with sanitizer (HS) treatment of peaches to reduce their surface microbial population and to determine the effect on shelf life and microbial quality. Three trials for RC and two trials each for FAC and HS were performed. Following cooling, fruit were stored at $1^{\circ} \mathrm{C}$. The average aerobic plate count (APC) from field samples was $5.29 \log \mathrm{cfu} /$ peach, which remained unchanged after RC or FAC but was reduced significantly $(P<0.05)$ to $4.63 \mathrm{log} \mathrm{cfu} / \mathrm{peach}$ after HS. The average yeast and mold counts (Y\&M) from field samples (6.21 log cfu/peach) were reduced highly significantly $(P<0.001)$ to $4.05 \mathrm{log} \mathrm{cfu} /$ peach after HS. Hydrocooling significantly $(P<0.05)$ reduced the APC and Y\&M counts from the peaches and showed promise in maintaining the microbiological quality of the fruit throughout storage. However, at the end of the 21-day storage period, there was no significant difference in APC or Y\&M counts from peaches, irrespective of the cooling methods. Peaches that went through the hydrocooling process and were subsequently packed showed an increase $(P<0.05)$ in both APC and Y\&M counts, while fruit that were not hydrocooled showed no such increase. Information obtained will be used to recommend the best temperature management practices for maintaining the postharvest quality of peaches. A detailed cost-benefit analysis of different cooling methods and the time interval between harvest and shipment are both necessary for a more conclusive recommendation.
\end{abstract}

$\mathrm{I}$ ncreasing awareness about healthy eating drives health-conscious consumers to eat peaches (Prunus persica) because this fruit is a good source of antioxidants, including vitamin $\mathrm{C}$ (Hashem et al., 2019; Noratto et al., 2014). The United States occupied the fourth position in peach production worldwide, with 638,020 tons of used production in 2018 with a value of $\$ 511,226$ (U.S. Department of Agriculture, 2019). Peach acreage in Florida had increased from 1231 in 2012 to 3000 in 2014 (Olmstead and Morgan, 2013; Olmstead et al., 2015; Singerman et al., 2017), though there has been a slight decrease with current estimates of $\approx 2000$ acres (A. Sarkhosh, personal communication). One of the main drivers for increased production is the availability of new peach cultivars from the University of Florida/Institute of Food and Agriculture Sciences breeding programs that are firmer, more flavorful, and better adapted to Florida's varied microclimates (Sarkhosh et al., 2016; Singerman et al., 2017). In addition, citrus (Citrus sp.) growers, facing declining production due to plant disease such as citrus greening (also known as Huanglongbing or HLB) caused by the bacteria Candidatus Liberibacter asiaticus, have started replacing citrus acreage with peaches (Nickel, 2018). During 2015, the Florida Department of Agriculture and Consumer Services (FDACS) Division of Food, Nutrition, and Wellness assisted 24 Florida school districts in procuring an estimated $108,595 \mathrm{lb}$ of peaches and was responsible for their incorporation into school meal menus (FDACS, 2015). Considering the increasing demand for peaches, postharvest processes that extend shelf life need further study for the benefit of the producer as well as the consumer.

Peach, as a temperate, climacteric fruit (Guohua et al., 2012; Hayama et al., 2006; Minas et al., 2018; Tonutti et al., 1991; Zhang et al., 2011) undergoes rapid ripening, which accounts for its short shelf life and represents a serious constraint for its efficient handling and transportation (Hussain et al., 2008). For this reason, peaches are often picked at a preclimacteric stage to withstand the handling process. However, in Florida, ripening initiated ("treeripe") peaches can be picked due to widespread planting of cultivars with the nonmelting flesh trait that imparts very firm texture (Sarkhosh et al., 2016). Owing to rapid ripening after harvest that results in a shortened shelf life, refrigeration is often used to store peaches. This has the beneficial effect of extending shelf life both by maintaining fruit quality and by reducing storage decay (Wang et al., 2005; Xi et al., 2012). Conversely, even though postharvest refrigeration prolongs shelf life of peaches, this fruit can easily suffer from chilling injury (CI) and thereby become more susceptible to microbial decay. CI, commonly called "internal breakdown," can cause flesh browning and poor overall texture ("mealiness") in the fruit (Anderson and Penney, 1975; Artés et al., 2006;

\begin{tabular}{llll}
\hline $\begin{array}{l}\text { Units } \\
\text { To convert U.S. to SI, } \\
\text { multiply by }\end{array}$ & U.S. unit & SI unit & $\begin{array}{l}\text { To convert SI to U.S., } \\
\text { multiply by }\end{array}$ \\
\hline 29,574 & $\mathrm{fl} \mathrm{oz}$ & $\mu \mathrm{L}$ & $3.3814 \times 10^{-5}$ \\
29.5735 & $\mathrm{fl} \mathrm{oz}$ & $\mathrm{mL}$ & 0.0338 \\
2.54 & inch $(\mathrm{es})$ & $\mathrm{cm}$ & 0.3937 \\
0.4536 & $\mathrm{lb}$ & $\mathrm{kg}$ & 2.2046 \\
1 & $\mathrm{ppm}$ & $\mu \mathrm{L} \cdot \mathrm{L}^{-1}$ & 1 \\
0.9072 & ton $(\mathrm{s})$ & $\mathrm{Mg}$ & 1.1023 \\
$\left({ }^{\circ} \mathrm{F}-32\right) \div 1.8$ & ${ }^{\circ} \mathrm{F}$ & ${ }^{\circ} \mathrm{C}$ & $\left({ }^{\circ} \mathrm{C} \times 1.8\right)+32$
\end{tabular}


Brovelli et al., 1998; Byrne, 2002; Crisosto et al., 1995, 1996; Lurie and Crisosto, 2005). As a result, several nondestructive methods have been developed that use acoustical or infrared (IR) energy to detect CI in peaches (Byrne, 2002), as well as irradiation treatment that inhibits ripening and decay (Hussain et al., 2008). However, such treatments still need more research before they can become commercially viable.

Proper temperature management has been shown to be critical in maintaining postharvest peach quality (Crisosto and Valero, 2008; Kader, 2003). However, current cooling practices used by peach growers often result in cooling delays up to $24 \mathrm{~h}$, compromising potential quality. In many production areas, peaches are typically picked and placed in a cold room on the day of harvest and packed and shipped on the following day (De et al., 2017). This form of cooling (room cooling) is the slowest method and requires 20 $\mathrm{h}$ or more for fruit to achieve $7 / 8$ cooling - a decrease in fruit temperature equal to $7 / 8$ of the difference between the initial fruit temperature and the cooling medium temperature (Sargent et al., 2017). Tree-ripe peaches are already undergoing rapid, climacteric ripening when they are harvested, which makes them highly perishable, thus making temperature management critical for long distance marketing to be successful. In addition to ripening, the longer the delay

Received for publication 13 Mar. 2020. Accepted for publication 7 May 2020.

Published online 30 June 2020.

${ }^{1}$ Department of Food Science and Human Nutrition, Institute of Food and Agricultural Sciences, University of Florida, Gainesville, FL 32611

${ }^{2}$ Horticultural Sciences Department, Institute of Food and Agricultural Sciences, University of Florida, Gainesville, FL 32611

This work was supported by the U.S. Department of Agriculture, Florida Specialty Crop Block Grant Program, under the project "Temperature Management for Quality and Safe Florida Blueberries and Peaches" (contract no. 00096305).

We thank the Florida peach growers for allowing use of their facilities.

Current address for M.J.: University of Central Florida, Burnett School of Biomedical Sciences, College of Medicine, 4110 Libra Drive, Biological Science Building, Suite 133, Orlando, FL 32816-2364.

K.R.S. is the corresponding author. E-mail: keiths29@ ufl.edu.

This is an open access article distributed under the CC BY-NC-ND license (https://creativecommons.org/ licenses/by-nc-nd/4.0/).

https://doi.org/10.21273/HORTTECH04609-20 to cooling, the more moisture is lost, and the more sensitive peaches are to bruising (Ahmadi et al., 2010; Opara and Pathare, 2014). The need exists to investigate the impact of cooling practices on postharvest quality and shelf life of peaches. Locally grown peaches have the potential to have far better quality than imported product during the harvest season. The increase in production of peaches and the growing demand is leading grower/shippers to explore alternative ways to expand their markets while still maintaining quality. With the increase in acreage and burgeoning markets for peaches comes a need for Florida grower/shippers to expand packing and cooling capabilities within the state. There is currently a lack of research on effective cooling practices, which is essential in decision making to assist in the upgrading of these facilities and the implementation of improved handling procedures.

This research was performed to compare and evaluate forced-air cooling (FAC) and hydrocooling by chilled water with sanitizer (HS) as alternatives to room cooling (RC). Determination of microbial load from the surface of untreated field (uncooled), and treated (cooled by RC, FAC, and HS) peaches (pre- and postpack) were performed to compare the efficacy of different postharvest cooling methods. In addition, the effect of these cooling methods in maintaining microbiological quality during a 21 $\mathrm{d}$ storage was evaluated. The goal of this research was to increase the competitiveness of growers, packers, and shippers of fresh-market peaches by improving and extending postharvest quality and ensuring microbiological safety by investigating the efficacy of cooling methods and postharvest temperature management.

\section{Materials and methods}

FRUIT AND COOLING METHODS. Freshly harvested 'UF Sun' peaches from several different orchards in Dundee, FL were collected in field lugs, palletized, transported to a packinghouse, and cooled by either RC, FAC, or HS. For RC, pallets were placed in a commercial cold room $\left(\approx 3.8{ }^{\circ} \mathrm{C}\right)$ and held overnight for $\approx 14-16 \mathrm{~h}$ until packing the next morning. In FAC trials, pallets were placed in the cold room and covered with a large plastic sheet over the top and two sides. A large fan pulled room air through the pallets for $\approx 2 \mathrm{~h}$, then the pallets were left overnight in the same room until packing the next morning. For HS, pallets were individually loaded into a prototype shower hydrocooler with commercial water flow rate and capacity to maintain the chilled water at 2 to $5{ }^{\circ} \mathrm{C}$ for $\approx \mathrm{l} \mathrm{h}$. The cooling water was maintained at $150-200 \mathrm{ppm}$ free chlorine $(\mathrm{Cl})$ at $\mathrm{pH}$ 7.0-7.3 during cooling. Water temperature and $\mathrm{pH}$ were measured by a combination $\mathrm{pH}$ and oxidation-reduction potential (ORP) meter (Hanna Instruments USA, Smithfield, $\mathrm{RI}$ ); and free $\mathrm{Cl}$ concentrations were measured using colorcoded strips (Aquacheck; Hach Co., Loveland, CO). Free chlorine levels were adjusted using a $5.7 \%$ to $6 \%$ sodium hypochlorite $(\mathrm{NaOCl})$ solution (Fisher Scientific, Fair Lawn, $\mathrm{NJ}$ ), and the $\mathrm{pH}$ was adjusted using muriatic acid (Hach Co.). Duration for the FAC and HS were chosen to achieve $7 / 8$ cooling.

Peaches for microbiological analyses were sampled from pallets (field, uncooled) and after cooling. Each sample was a composite of five peaches (diameter $\approx 6.5 \mathrm{~cm}$ ) and was collected in sterile plastic bags (Stomacher; Seward, Bohemia, NY). Peaches were also sampled and microbiologically analyzed before and after packing to see if there was any effect of handling before they were packed for shipment. While packing was performed by professional workers, all sampling and microbiological analyses were performed by trained laboratory personnel. All peach samples, collected either from pallets or after cooling at the packing house, were transported in insulated coolers to the laboratory in Gainesville, FL and immediately analyzed for aerobic plate counts (APC) and yeast and mold counts (Y\&M). Cooled peaches were stored at $1.1^{\circ} \mathrm{C}$ for $21 \mathrm{~d}$ for the shelf-life study. Representative samples were withdrawn on days $0,1,7,14$, and 21 . At each sampling time, three replicates were sampled. Each sample consisted of five fruits. Peaches collected from the pallets for microbiological analyses were not included in the shelf-life experiments. Three trials for RC and two trials each for FAC and HS were conducted. Different trials were run concurrently. All trials were conducted between 11 Apr. and 10 May 2016. 
Except the sampling day in early May 2016 for the third trial, the weather was sunny, hot, and humid. There was a heavy rainfall on the day before the sampling day for the third trial.

Microbiological anALYSIS. A 100-mL aliquot of $0.1 \%(\mathrm{w} / \mathrm{v})$ sterile peptone water (PW) (Thermo Fisher Scientific, Waltham, MA) was added to the sterile sample bags and each peach was rubbed for $30 \mathrm{~s}$ to remove surface bacteria. Bacterial enumeration was performed by 10 -fold serial dilution in $0.1 \%(\mathrm{w} / \mathrm{v}) \mathrm{PW}$. A $100-\mu \mathrm{L}$ portion of each dilution was spreadplated onto plate count agar (PCA) (Difco; Becton, Dickinson and Co., Sparks, MD) to determine total mesophilic APC and on potato dextrose agar (PDA) (Difco; Becton, Dickinson and Co.) for Y\&M counts. Peaches from the post-packing line were stored at $1.1{ }^{\circ} \mathrm{C}$ for $21 \mathrm{~d}$. Representative samples were withdrawn on days $0,1,7,14$, and 21; each were processed for microbiological analysis in the same manner as described above.

Statistical analysis. Triplicate sets of samples, each set containing five peaches, were collected at each time point starting from the field pallets through to the end of the storage experiment. The RC experiment was repeated three times $(\mathrm{n}=$ 3 ), whereas the FAC and HS experiments were performed twice $(\mathrm{n}=2)$. Bacterial counts were $\log \left(\log _{10}\right)$ transformed before statistical analysis. The limit of detection (LOD) for colony counts was set to $\log 1.3$ cfu/peach. Multifactorial regression analysis of the response variables (APC and Y\&M) for treatment (RC, FAC, HS), day $(0,1,7,14$, and 21$)$, and trial $(1,2,3$, and 4$)$ were performed. One-way analysis of variance, $F$-test (two-sample for variances), and $t$ test for individual sample set with unequal variance were performed to determine the effects of different cooling methods on the microbial quality of peaches during postharvest cooling, handling, and storage. Means were calculated and comparisons for all pairs were performed using the Tukey-Kramer honestly significant difference analysis. The level of confidence $(\alpha)$ was set at 0.05 . All statistical analysis was performed using JMP Pro (version 14; SAS Institute, Cary, NC) and Microsoft Excel (version 1808, Microsoft
Office 365 ProPlus; Microsoft Corp., Redmond, WA).

\section{Results}

Pulp temperatures of the freshly harvested fruit were 29 to $32{ }^{\circ} \mathrm{C}$ and the fruit were cooled to $\approx 6.7$ and $3.8{ }^{\circ} \mathrm{C}$ after $\mathrm{FAC}$ and $\mathrm{HS}$, respectively. There were differences between trials for APC and Y\&M counts from peaches. Field samples were compared among four trials, whereas RC samples were compared among three trials. The FAC and HS samples were compared among the last two trials (Tables 1 and 2) because they were not performed in the first two trials. The APC in field and $\mathrm{RC}$ samples were the highest in the third trial (Table 1). There was no significant difference $(P>0.05)$ among trials in $Y \& M$ counts from field samples or in FAC or HS samples, but the RC samples had significantly higher $Y \& M$ counts in the third trial (Table 2). The average APC from field samples was 5.29 log cfu/peach, which remained almost unchanged after RC or FAC, but it was significantly $(P<0.05)$ reduced to $4.63 \log$ cfu/peach after HS (Table $3)$. The average $Y \& M$ counts from field samples (6.22 log cfu/peach) was reduced highly significantly $(P<$ $0.001)$ to $4.05 \log \mathrm{cfu} /$ peach after HS (Table 4).

Sorting and packing significantly increased both APC and Y\&M counts on hydrocooled peaches $(P<0.05)$, while these activities showed no such effect on RC or FAC peaches. The APC on RC peaches remained unchanged (5.20 log cfu/peach) before and after packing. These counts increased slightly $(P>0.05)$ on FAC peaches, from 5.35 to $5.60 \log \mathrm{cfu} /$ peach, before and after packing, respectively. The APC on HS peaches increased significantly $(P<0.05)$, from 4.63 to $5.18 \mathrm{log}$ cfu/peach, before and after packing, respectively. The Y\&M counts on RC peaches was reduced from 6.11 to $6.02 \mathrm{log}$ $\mathrm{cfu} /$ peach from before to after packing. These counts increased slightly $(P>0.05)$ on FAC peaches, from 6.07 to $6.14 \log \mathrm{cfu} /$ peach, from before to after packing. The Y\&M

Table 1. Comparison of aerobic plate counts (APC) on uncooled peaches and those cooled by room cooling (RC), forced-air cooling (FAC), and hydrocooling with sanitizer (HS).

\begin{tabular}{|c|c|c|c|c|}
\hline \multirow[b]{3}{*}{ Trial no. } & \multicolumn{4}{|c|}{ Treatment $^{\mathrm{z}}$} \\
\hline & Field & RC & FAC & HS \\
\hline & \multicolumn{4}{|c|}{ APC [least square mean \pm SE $(\log \mathrm{cfu} /$ peach $)]^{\mathrm{y}}$} \\
\hline 1 & $4.73 \pm 0.17 b^{x}$ & $4.33 \pm 0.13 c$ & NT & NT \\
\hline 2 & $4.73 \pm 0.17 \mathrm{~b}$ & $5.03 \pm 0.13 \mathrm{~b}$ & NT & NT \\
\hline 3 & $6.16 \pm 0.17 \mathrm{a}$ & $6.20 \pm 0.13 \mathrm{a}$ & $4.63 \pm 0.03 \mathrm{~b}$ & $4.37 \pm 0.06 b$ \\
\hline 4 & $5.57 \pm 0.17 \mathrm{a}$ & NT & $6.06 \pm 0.03 \mathrm{a}$ & $4.90 \pm 0.06 \mathrm{a}$ \\
\hline
\end{tabular}

${ }^{\mathrm{z}} \mathrm{RC}$ treatment was $14-16 \mathrm{~h}$. FAC and HS treatments were 2 and $\mathrm{l}$ h, respectively.

${ }^{y}$ Reported values are of APC from four individual trials. RC was performed three times $(n=3) ;$ FAC and HS were performed two times each $(\mathrm{n}=2)$; NT $=$ not tested.

${ }^{x}$ Values with the same letters within columns for the same treatment are not significantly different $(P>0.05)$ via Tukey-Kramer honestly significant difference analysis.

Table 2. Comparison of yeast and mold counts (Y\&M) on uncooled peaches and those cooled by room cooling (RC), forced-air cooling (FAC), and hydrocooling with sanitizer (HS).

\begin{tabular}{|c|c|c|c|c|}
\hline \multirow[b]{3}{*}{ Trial no. } & \multicolumn{4}{|c|}{ Treatment $^{\mathrm{z}}$} \\
\hline & Field & $\mathrm{RC}$ & FAC & HS \\
\hline & \multicolumn{4}{|c|}{ Y\&M [least square mean \pm SE $(\log \mathrm{cfu} /$ peach $)]^{\mathrm{y}}$} \\
\hline 1 & $6.43 \pm 0.17 \mathrm{a}^{\mathrm{x}}$ & $6.00 \pm 0.05 b$ & NT & NT \\
\hline 2 & $6.03 \pm 0.17 \mathrm{a}$ & $5.96 \pm 0.05 \mathrm{~b}$ & NT & NT \\
\hline 3 & $6.27 \pm 0.17 \mathrm{a}$ & $6.33 \pm 0.05 a$ & $6.01 \pm 0.10 \mathrm{a}$ & $3.97 \pm 0.21 \mathrm{a}$ \\
\hline 4 & $6.17 \pm 0.17 \mathrm{a}$ & NT & $6.10 \pm 0.10 \mathrm{a}$ & $4.13 \pm 0.21 \mathrm{a}$ \\
\hline
\end{tabular}


Table 3. Effect of postharvest room cooling (RC), forced-air cooling (FAC), and hydrocooling with sanitizer (HS) on aerobic plate counts (APC) during peach storage.

\begin{tabular}{lcccc}
\hline & \multicolumn{4}{c}{ Treatment $^{\mathrm{y}}$} \\
\cline { 2 - 5 } Storage $(\mathrm{d})^{\mathrm{z}}$ & Field & RC & FAC & HS \\
\cline { 2 - 5 } & & APC $[\text { mean } \pm \text { SE }(\log \text { cfu/peach })]^{\mathrm{x}}$ & \\
\hline 0 & $5.29 \pm 0.11 \mathrm{a}^{\mathrm{w}}$ & $5.19 \pm 0.23 \mathrm{a} \mathrm{A}^{\mathrm{w}}$ & $5.35 \pm 0.19$ a A & $4.63 \pm 0.16 \mathrm{~b} \mathrm{~B}$ \\
1 & $\mathrm{NT}$ & $5.18 \pm 0.23$ a A & $5.62 \pm 0.19$ a A & $5.18 \pm 0.16 \mathrm{ab} \mathrm{AB}$ \\
7 & $\mathrm{NT}$ & $5.23 \pm 0.23$ a A & $5.15 \pm 0.19$ a A & $5.50 \pm 0.16 \mathrm{a} \mathrm{A}$ \\
14 & $\mathrm{NT}$ & $5.24 \pm 0.23$ a A & $5.23 \pm 0.19$ a A & $4.75 \pm 0.16 \mathrm{~b} \mathrm{~B}$ \\
21 & $\mathrm{NT}$ & $4.90 \pm 0.23$ a A & $4.85 \pm 0.19$ a A & $4.80 \pm 0.16 \mathrm{~b} \mathrm{~B}$ \\
\hline
\end{tabular}

${ }^{\mathrm{z}}$ Day 0 values were obtained immediately after harvesting (field) and cooling treatments. Day $\mathrm{l}$ values were obtained from packed samples.

${ }^{\mathrm{y}} \mathrm{RC}$ treatment was $14-16 \mathrm{~h}$. FAC and HS treatments were 2 and $\mathrm{l} \mathrm{h}$, respectively.

${ }^{\mathrm{x}}$ Reported values are of APC from all trials. RC was performed three times $(\mathrm{n}=3)$; FAC and HS were performed two times each $(\mathrm{n}=2)$; NT $=$ not tested.

wValues with the same letters within columns $(\mathrm{a}, \mathrm{b}, \mathrm{c})$ for the same treatment, or within rows $(\mathrm{A}, \mathrm{B}, \mathrm{C})$ for the same day, are not significantly different $(P>0.05)$ via Tukey-Kramer honestly significant difference analysis.

Table 4. Effect of postharvest room cooling (RC), forced-air cooling (FAC), and hydrocooling with sanitizer (HS) on yeast and mold counts (Y\&M) during peach storage.

\begin{tabular}{lcccc}
\hline & \multicolumn{4}{c}{ Treatment $^{\mathrm{y}}$} \\
\cline { 2 - 5 } $\begin{array}{l}\text { Storage } \\
(\mathrm{d})^{\mathrm{z}}\end{array}$ & Field & \multicolumn{4}{c}{ RC } & \multicolumn{2}{c}{ FAC } & HS \\
\cline { 2 - 5 } 0 & \multicolumn{4}{c}{ Y\&Mean \pm SE $(\log \mathrm{cfu} /$ peach $)]^{\mathrm{x}}$} \\
1 & $6.22 \pm 0.11 \mathrm{a}^{\mathrm{w}}$ & $6.11 \pm 0.06 \mathrm{a} \mathrm{A}^{\mathrm{w}}$ & $6.08 \pm 0.07 \mathrm{ab} \mathrm{A}$ & $4.05 \pm 0.16 \mathrm{c} \mathrm{C}$ \\
7 & $\mathrm{NT}$ & $6.03 \pm 0.06 \mathrm{a} \mathrm{A}$ & $6.17 \pm 0.07 \mathrm{a} \mathrm{A}$ & $5.21 \pm 0.16 \mathrm{~b} \mathrm{~B}$ \\
14 & $\mathrm{NT}$ & $6.06 \pm 0.06 \mathrm{a} \mathrm{A}$ & $5.95 \pm 0.07 \mathrm{~b} \mathrm{AB}$ & $5.95 \pm 0.16 \mathrm{a} \mathrm{A}$ \\
21 & $\mathrm{NT}$ & $6.20 \pm 0.06 \mathrm{a} \mathrm{A}$ & $5.90 \pm 0.07 \mathrm{bc} \mathrm{AB}$ & $5.23 \pm 0.16 \mathrm{~b} \mathrm{~B}$ \\
& $\mathrm{NT}$ & $6.17 \pm 0.06 \mathrm{a} \mathrm{A}$ & $5.73 \pm 0.07 \mathrm{c} \mathrm{B}$ & $5.83 \pm 0.16 \mathrm{ab} \mathrm{AB}$ \\
\hline
\end{tabular}

${ }^{\mathrm{z}}$ Day 0 values were obtained immediately after harvesting (field) and cooling treatments. Day $\mathrm{l}$ values were obtained from packed samples.

${ }^{\mathrm{y}} \mathrm{RC}$ treatment was $14-16 \mathrm{~h}$. FAC and HS treatments were 2 and $\mathrm{l} \mathrm{h}$, respectively.

${ }^{\mathrm{x}}$ Reported values are of Y\&M from all trials. RC were performed three times each $(\mathrm{n}=3)$; FAC and HS were performed two times each $(\mathrm{n}=2)$; NT = not tested.

"Values with the same letters within columns $(a, b, c)$ for the same treatment, or within rows $(A, B, C)$ for the same day, are not significantly different $(P>0.05)$ via Tukey-Kramer honestly significant difference analysis.

counts on HS peaches increased significantly $(P<0.05)$, from 4.05 to $5.21 \log \mathrm{cfu} /$ peach, from before to after packing.

Cooling peaches by HS significantly reduced $(P<0.05)$ the APC from $5.29 \log \mathrm{cfu} /$ peach on uncooled (field) peaches to $4.63 \mathrm{log}$ $\mathrm{cfu} /$ peach on day 0 samples. There was no such effect noted for RC nor FAC, where the APC on peaches remained almost the same until day 14. At the end of the 21-d storage period, there was no significant effect of different cooling methods on the APC (Table 3 ). The average Y\&M counts significantly $(P<0.05)$ declined, from $6.22 \mathrm{log} \mathrm{cfu} / \mathrm{peach}$ on uncooled (field) peaches to $4.05 \mathrm{log}$ $\mathrm{cfu} /$ peach on HS peaches. Reduction of $Y \& M$ counts were not significant for RC (6.11 log cfu/peach) nor FAC (6.08 log cfu/peach) peaches (Table
4). At the end of the 2l-d storage period, the $\mathrm{Y} \& \mathrm{M}$ counts on $\mathrm{RC}$ peaches were $6.17 \log \mathrm{cfu} /$ peach, which was significantly higher $(P<$ $0.05)$ than the FAC $(5.73 \log \mathrm{cfu} /$ peach) or HS (5.83 log cfu/peach) peaches (Table 4 ).

\section{Discussion}

The quality of peaches after harvest can only be maintained, not improved, a situation that makes temperature management crucial for reducing the rate of losses of quality. Similarly, effective temperature management contributes to the microbial quality of peach fruit by reducing the rate of microbial proliferation during storage and marketing. Peaches can be damaged by rough handling, especially when picked at an advanced (tree ripe) stage of development. Peaches are highly perishable after harvest, and cold storage is required to minimize deterioration rates and delay softening. For this reason, packers and shippers emphasize means to maintain firm fruit to aid in maximizing the storage, shipping, and retail market life potential (Crisosto and Costa, 2008). Cooling fruit to $7 / 8$ cool before packing and shipping can extend shelf life. It has been recommended that peaches picked at the preclimacteric stage should be cooled to 5 to $10{ }^{\circ} \mathrm{C}$ within 6 to 8 $\mathrm{h}$, and to $0{ }^{\circ} \mathrm{C}$ within $24 \mathrm{~h}$ of harvest, whereas tree-ripe peaches should be cooled to near $0^{\circ} \mathrm{C}$ within 6 to $8 \mathrm{~h}$ of harvest (Crisosto et al., 1995). In the present study, uncooled field samples were used only to determine initial microbial loads and were not included in the storage experiment. These initial microbial loads were compared with those taken from peaches following cooling to determine the effects of cooling method on microbial populations.

Postharvest loss of stone fruits to decay-causing fungi is considered the greatest deterioration problem (Crisosto et al., 1995). Worldwide, the most important pathogen of fresh stone fruits is grey mold or botrytis rot, caused by the fungus Botrytis cinerea. In southern Florida, though not to a greater extent, cause of loss due to decay is caused by the brown rot fungi Monilinia fructicola, Monilinia laxa, or Monilinia fructigena (Bernat et al., 2017; Garcia-Benitez et al., 2017). These fungi have different survival potentials and can proliferate during refrigerated storage (Garcia-Benitez et al., 2017) or at higher temperatures $\left(30\right.$ to $33^{\circ} \mathrm{C}$ ) (Bernat et al., 2017). During the 21d storage there was a significant increase in $Y \& M$ counts on HS peaches, though their identification was beyond the scope of the current study.

In this study APC counts on the fruit did not increase significantly during storage-thus maintained microbiological quality irrespective of the cooling method used. The APC on incoming field fruit was significantly higher $(P<0.05)$ in the third trial than in the other two trials (Table 1 ), possibly due to heavy rainfall before harvest. The HS in this experiment resulted in rapid cooling of the fruit and significantly greater reduction of the postharvest loads of APC and $Y \& M$ on the peaches and showed 
promise in maintaining the microbiological quality of the fruit throughout the storage. Both RC and FAC also were able to keep the microbiological load of the peaches under control; though, unlike the HS, they did not reduce the initial loads on the peaches. However, at the end of the $2 \mathrm{l}-\mathrm{d}$ storage period there was no difference in microbiological quality of the peaches, irrespective of the cooling method used. An important factor to be considered here is the time involved in the three different cooling methods. In that regard, RC took overnight, FAC took $2 \mathrm{~h}$, whereas HS took about $1 \mathrm{~h}$ to reach the target $7 / 8$ cooling temperature. Peaches that were hydrocooled (HS) and subsequently packed showed an increase $(P<0.05)$ in both APC and $Y \& M$ counts, while fruit that were not hydrocooled showed no such increase. This increase could possibly be due to handling of the wet peaches during packing, negating the benefits seen in peaches sampled directly post HS. Initial sanitation during hydrocooling (only used on the HS) reduced microbial load compared with RC and FAC. However, the benefits rapidly disappeared during cold storage. Thus, this result demonstrated that sanitation must be enforced and supervised during all packing process.

While considering the efficacy of these cooling methods, a detailed economic analysis comparing all the three methods is necessary to reach any conclusion and make a recommendation to peach handlers. Peaches cooled by HS had lower microbial loads compared with the peaches cooled by the other two methods. Moreover, HS peaches, owing to shorter cooling time, could also be available for packing and shipping on the day of harvest, which would reduce the delay in shipment and market distribution of peaches.

\section{Literature cited}

Ahmadi, E., H.R. Ghassemzadeh, M. Sadeghi, M. Moghaddam, and S.Z. Neshat. 2010. The effect of impact and fruit properties on the bruising of peach. J. Food Eng. 97:110-117.

Anderson, R.E. and R.W. Penney. 1975. Intermittent warming of peaches and nectarines stored in a controlled atmosphere or air. J. Amer. Soc. Hort. Sci. 100:151-153.
Artés, F., P.A. Gómez, and F. ArtésHernández. 2006. Physical, physiological and microbial deterioration of minimally fresh processed fruits and vegetables. Food Sci. Technol. Intl. 13:177-178.

Bernat, M., J. Segarra, C. Casals, N. Teixidó, R. Torres, and J. Usall. 2017. Relevance of the main postharvest handling operations on the development of brown rot disease on stone fruits. J. Sci. Food Agr. 97:5319-5326.

Brovelli, E.A., J.K. Brecht, W.B. Sherman, and C.A. Sims. 1998. Quality of fresh-market melting- and nonmeltingflesh peach genotypes as affected by postharvest chilling. J. Food Sci. 63:730733.

Byrne, D.H. 2002. Peach breeding trends: A world wide perspective. Acta Hort. 592:49-59.

Crisosto, C.H. and D. Valero. 2008. Harvesting and postharvest handling of peaches for the fresh market, p. 575-596. In: D.R. Layne and D. Bassi (eds.). The peach: Botany, production and uses. $\mathrm{CAB}$ Intl., Wallingford, UK.

Crisosto, C.H., F.G. Mitchell, and S. Johnson. 1995. Factors in fresh market stone fruit quality. Postharvest News Inf. $6: 17 \mathrm{~N}-21 \mathrm{~N}$.

Crisosto, C.H., E.J. Mitcham, and A.A. Kader. 1996. Peaches and nectarines. Recommendations for maintaining postharvest quality. Perishables Handling Nwsl. 86:17-18.

Crisosto, C.H. and G. Costa. 2008. Preharvest factors affecting peach quality, $\mathrm{p}$. 536-549. In: D.R. Layne and D. Bassi (eds.). The peach: Botany, production and uses. CAB Intl., Wallingford, UK.

De, J., B. Bertoldi, A. Gutierrez, J. Mohammad, S. Sargent, and K.R. Schneider. 2017. Effect of postharvest cooling on the microbial quality and storage of Florida peaches. Intl. Assn. Food Protection (IAFP) Annu. Mtg., 9-12 July 2017, Tampa, FL. Pl-44. J. Food Prot. Supplement p. 98.

Florida Department of Agriculture and Consumer Services (FDACS). 2015. Annual report. 25 Dec. 2019. <https://www. freshfromflorida.com/content/download/ 68787/1616663/2015-FDACS-AnnualReport.pdf $>$.

Garcia-Benitez, C., P. Melgarejo, and A. De Cal. 2017. Fruit maturity and postharvest environmental conditions influence the pre-penetration stages of Monilinia infections in peaches. Intl. J. Food Microbiol. 241:117-122.

Guohua, H., W. Yuling, Y. Dandan, D. Wenwen, Z. Linshan, and W. Lvye. 2012.
Study of peach freshness predictive method based on electronic nose. Food Control 28:25-32.

Hashem, M., S.A.M. Alamri, M.S.A. Alqahtani, and S.R.Z. Alshehri. 2019. A multiple volatile oil blend prolongs the shelf life of peach fruit and suppresses postharvest spoilage. Scientia Hort. 251:48-58.

Hayama, H., M. Tatsuki, A. Ito, and Y. Kashimura. 2006. Ethylene and fruit softening in the stony hard mutation in peach. Postharvest Biol. Technol. 41:1621.

Hussain, P.R., R.S. Meena, M.A. Dar, and A.M. Wani. 2008. Studies on enhancing the keeping quality of peach (Prunus persica Bausch) cv. Elberta by gamma-irradiation. Radiat. Phys. Chem. 77:473481 .

Kader, A.A. 2003. A perspective on postharvest horticulture (1978-2003). HortScience 38:1004-1008.

Lurie, S. and C.H. Crisosto. 2005. Chilling injury in peach and nectarine. Postharvest Biol. Technol. 37:195-208.

Minas, I.S., T. Georgia, and A. Molassiotis. 2018. Environmental and orchard bases of peach fruit quality. Scientia Hort. 235:307-322.

Nickel, A. 2018. Growers optimistic for Florida crop. 25 Dec. 2019. <https:// www.thepacker.com/article/growersoptimistic-florida-peach-crop>.

Noratto, G., W. Porter, D. Byrne, and L. Cisneros-Zevallos. 2014. Polyphenolics from peach (Prunus persica var. Rich Lady) inhibit tumor growth and metastasis of MDA-MB-435 breast cancer cells in vivo. J. Nutr. Biochem. 25:796-800.

Olmstead, M. and K. Morgan. 2013. Orchard establishment budget for peaches and nectarines in Florida. 25 Dec. 2019. $<$ http://edis.ifas.ufl.edu/hs1223>.

Olmstead, M.A., J.L. Gilbert, T.A. Colquhoun, D.G. Clark, R. Kluson, and H.R. Moskowitz. 2015. In pursuit of the perfect peach: Consumer-assisted selection of peach fruit traits. HortScience 50:12021212.

Opara, L.U. and B.P. Pathare. 2014. Bruise damage measurement and analysis of fresh horticultural produce-A review. Postharvest Biol. Technol. 91:9-24.

Sargent, S.A., A.D. Berry, J.K. Brecht, M. Santana, S. Zhang, and N. Ristow. 2017. Studies on quality of southern highbush blueberry cultivars: Effects of pulp temperature, impact and hydrocooling. Acta Hort. 1180:497-502. 
Sarkhosh, A., M.A. Olmstead, J.X. Chaparro, P. Andersen, and J. Williamson. 2016. Florida peach and nectarine varieties. $25 \mathrm{Dec}$. 2019. <http://edis.ifas.ufl.edu/mg374>.

Singerman, A., M. Burani-Arouca, and M. Olmstead. 2017. Establishment and production costs for peach orchards in Florida: Enterprise budget and profitability analysis. 25 Dec. 2019. <https://edis.ifas.ufl. edu/pdffiles/FE/FE101600.pdf>.

Tonutti, P., P. Casson, and R. Ramina. 1991. Ethylene biosynthesis during peach fruit development. J. Amer. Soc. Hort. Sci. 116:274-279.
U.S. Department of Agriculture. 2019. Noncitrus Fruits and Nuts: 2018 Summary. June 2019. <https://www.nass.usda.gov/ Publications/Todays_Reports/reports / ncit0619.pdf>.

Wang, Y.-S., S.-P. Tian, and Y. Xu. 2005. Effects of high oxygen concentration on pro- and anti-oxidant enzymes in peach fruits during postharvest periods. Food Chem. 91:99-104.
Xi, W.-P., B. Zhang, L. Liang, J.-Y. Shen, W.-W. Wei, C.-J. Xu, A.C. Allan, I.B. Ferguson, and K.-S. Chen. 2012. Postharvest temperature influences volatile lactone production via regulation of acylCoA oxidases in peach fruit. Plant Cell Environ. 35:534-545.

Zhang, L., Z. Yu, L. Jiang, J. Jiang, H. Luo, and L. Fu. 2011. Effect of postharvest heat treatment on proteome change of peach fruit during ripening. J. Proteomics 74:1135-1149. 